\title{
Smaller US firms more aggressive with federal grants
}

Small high-tech companies are more intent on turning federal grants into patents, licenses, and product introductions than larger companies, according to a study by the US Department of Commerce's National Institute of Standards and Technology (Powell, J.W. 1998. Small-firm experience in the advanced technology program. NIST, Gaithersburg, $\mathrm{MD})$. The results of the study refute criticisms that federal support of high-technology is a waste of public money.

The grants in question come from the Advanced Technology Program (ATP), which was set up in 1990 by the US Department of Commerce. The ATP goal has been to spur economic growth and provide new jobs by fostering enabling technologies that are globally competitive and industry-driven. ATP awards are made on the basis of peerreviewed competitions. Proposals are selected based on best-quality technology, potential economic benefit to the nation, and potential for eventual commercialization.

The recently published study-the first of several intended by the NIST to assess progress of high-tech firms receiving ATP grants-looked at 388 ATP grantees working on 208 projects. Of these, $37 \%$ are small firms (less than 500 employees), 31\% mediumsized, $21 \%$ are large (Fortune 500-type) corporations, and $11 \%$ are universities or nonprofit organizations involved in joint ventures. The study examined grantees' 1993-1996 project goals, strategies, and progress toward commercialization, the overall effects of ATP funding, and the benefits for small firms of collaborating with larger ATP partners.

Results show that small firms are more aggressive in terms of their actual achievement of self-assigned goals, such as productive collaborations, bringing products to market, and cost-reduction, compared with all organizations receiving grants. More small firms $(54 \%)$ had set up pilot production for a commercial demonstration for at least one application, compared with all companies (42\%), and more small firms (20\%) had begun production of at least one application, compared with all organizations (11\%). After three years of funding, small firms had received an average of 1.1 patents per company, compared with 1.05 for larger companies. Small firms also place more emphasis on strategic alliances and other supply-chain linkages, and more frequently report collaboration-based success in raising capital (57\% of small firms reported an increase in internal

Neil Swan is a freelance writer working in Falls Church, VA. industry funds resulting from ATP, compared with $39 \%$ of all companies).

Critics have complained that ATP is unnecessary, sometimes benefiting giant corporations that should fund their own R\&D. This has prompted claims in past years from both liberals and conservatives that a misdirected ATP is dispensing "corporate welfare" to undeserving large companies.

However, ATP administrators say the program has been modified since its inception to focus more on assisting small businesses, and that single ATP grantees are required to pay all indirect project costs, thus encouraging small companies and start-ups, which have relatively low overheads.

Other critics have claimed that ATP is an unnecessary intrusion into the realm of venture capital and that funding tiny, fledgling companies in truly high-risk ventures is still a waste of public money.

ATP's supporters-prior grant recipients, industry trade groups, and some members of the US Congress-assert that ATP funding is critical to developing high-risk technologies that are usually far too hazardous to interest venture capitalists, and that the program helps boost US competitiveness in the exploding global high-tech marketplace.

GeneTrace Systems (Alameda, CA), a highthroughput genomics and proteomics company, is one of a number of biotechnology firms that has benefited from ATP grants. Although originally a spin-off from SRI International in 1994, GeneTrace was "basically just a couple of guys and an idea," says cofounder and president Christopher Becker. Receipt of a \$2 million ATP grant in early 1995 "really launched us, allowing us to hire people," he says, "Although we were still small, the grant allowed us to be something real." Today, GeneTrace has 60 employees, 14 patent applications, brand-new quarters, and several important deals, including one with investor-collaborator Monsanto (St. Louis, MO). Several other major pharmaceutical companies are interested in research and development partnerships, says Becker.

Since 1990, ATP has issued 431 awards totaling nearly $\$ 1.4$ billion, $\$ 124$ million of which funded DNA technologies, matched by $\$ 114$ million in industry cost-sharing. Since 1994, the bulk of ATP funding has gone to focused program areas, including 32 projects in “Tools for DNA Diagnostics."

For Nanogen (San Diego, CA), a chip developer for biomedical research and genomics, ATP funding from two \$2 million grants in 1995 and 1996 (matched by California state funding) was "like a godsend" in "getting us going as a company and moving faster into areas that we might have had to wait on," says James O'Connell, vice president of research. Nanogen's ATP research led to advances demonstrating the potential of its bioelectronic chip platform for the isolation, purification, and analysis of microbial DNA/RNA from a whole blood sample (Nat. Biotechnol. 16:541-546, 1998).

ATP funding is important because "you must have a certain level of critical mass" to establish credibility, says Ray Salemme, president of 3-Dimensional Pharmaceuticals (Exton, PA). The company has tripled its workforce to 90 employees since receiving a $\$ 2$ million ATP grant in 1995 to explore structurebased drug design using X-ray crystallography, combinatorial chemistry, and high-throughput screening technology.

Some observers say ATP is a "godfather" of the fledgling US biochip industry. For example, Affymetrix (Santa Clara, CA) introduced the first biochip in 1996, having allied itself in 1996 with Molecular Dynamics (Sunnyvale, CA). The firms, both then small and private, formed a joint venture that eventually involved several universities. The two companies received $\$ 31.5$ million in ATP grants between them-\$20.8 million to Affymetrix and $\$ 10.7$ million to Molecular Dynamics. Affymetrix, which went public in June of 1995, has used its grant to develop a handheld integrated nucleic-acid sample preparation cartridge, which it is now testing.

Vysis (Downers Grove, IL), a 1989 spin-off from Amoco (Naperville, IL), has also benefited from two \$2-million ATP grants for two projects, one leading to the introduction in October of the company's GenoSensor system, a package that includes unique genomic DNA chips, imaging hardware and software, and reagents for advanced DNA analysis. "Twothirds of all of Vysis' current technology, and all of our future technology, can be traced back to ATP funding," says Uwe Muller, the company's director of advanced technology.

Understandably, all these companies extol the virtues of ATP, saying it enables US companies to move into untapped areas of biotechnology, quickly scoring achievements that are essentially unrivaled in Europe or Japan. "I know the ATP program has been a political issue," says Becker of GeneTrace, "but I can speak for small companies in saying that the government stepped up to provide us funds and took risks where the venture capitalists would not. The result has been to greatly enhance the development of genetic tools."

The 1999 ATP budget is $\$ 203.5$ million, up from $\$ 192.5$ million this year but down from its peak funding of $\$ 341$ million in 1995. NIST will continue to monitor ATP's economic outcomes.

Neil Swan 